\title{
Status, Challenges and Future Prospects of Wastewater Reuse for Agricultural Irrigation in Developing Countries: A Mini Review
}

\author{
Sandeep Singh Shekhawat ${ }^{1}$, Kavita Verma ${ }^{2}$ and AB Gupta ${ }^{1 *}$ \\ ${ }^{1}$ Department of Civil Engineering, MNIT Jaipur, India \\ ${ }^{2}$ JNTUH, Hyderabad, India \\ *Corresponding Author: AB Gupta, Department of Civil Engineering, MNIT Jaipur, \\ India.
}

Received: April 02, 2020

Published: May 26, 2020

(c) All rights are reserved by $\mathbf{A B}$ Gupta. et al.

\section{Abstract}

Wastewater is becoming an important alternative resource to reduce water foot prints in many sectors. Agricultural irrigation sector accounts for the maximum (approximately 70\%) use of fresh water worldwide. With increasing scarcity of fresh water resources, many developing countries have been using untreated or partially treated wastewaters for irrigation. Aim of this review is to present the status of wastewater generation, treatment and reuse in irrigation across major developing nations. These countries were selected on the basis of high population, low national water stress ranking (NWSR) and data availability (Table 1 and 2). Further, current challenges of presence of pathogens, antibiotics and antibiotic resistant bacteria in high concentrations in wastewaters reused for irrigation have been critically discussed. The wastewater generation data across these nations show a large range of $0.0805-58.92 \mathrm{~km}^{3} /$ year, out of which barely $0.022-17.89 \mathrm{~km} 3 /$ year receives treatment. The vegetables (mostly lettuce) irrigated with wastewaters have reported high contamination of pathogens such as Enterococci, Salmonella, Vibrio, Clostridium, Klebsiella, helminth eggs. Similar results have been obtained for ARBs. Antibiotics concentrations reported in wastewater used for irrigation were up to $368 \mathrm{mg} / \mathrm{L}$ and up to many $\mu \mathrm{g} / \mathrm{Kg}$ of antibiotics in plant tissues have been found to accumulate in edible crops raised with such waters. Antibiotics SMX and CIP were most widely present in wastewaters due to their excessive use in these countries as well as their persistence. Existing treatment technologies have not been found to be suitable to remove all these emerging pollutants from wastewaters. Moreover, lack of data on such pollutants from developing nations is the major challenge to tackle the problems associated with safe wastewater reuse and calls for appropriate policy reforms and development of upgraded technology to combat such issues. Therefore, it is suggested that regular detailed research inputs are required to ensure long term sustainability for a safe reuse of this misplaced resource to conserve human and environmental health.

Keywords: Agricultural Irrigation; Developing Countries; Antibiotics; Antibiotic Resistant Bacteria; Wastewater Reuse; Wastewater Treatment Plants

\section{Introduction}

Agricultural irrigation for crop production largely accounts for approximately $70 \%$ of total freshwater withdrawals [1]. It has been increasing with population growth and meeting the food demands worldwide. Wastewater, as an alternative water resource, has been increasingly reused to cope up with the water deficit [2]. In recent years, this has rapidly increased in developed nations. With advancement in technology and acceptance among developed nations for the reuse of wastewaters, its scope has broadened from irrigation to indirect and direct potable purposes [3]. An urgent attention must be given by the developing nations for wastewater reuse, which are the largest (up to 93\%) users of freshwater for irrigation (Table 1). It has been estimates that more than $20 \mathrm{M}$ ha of croplands are being irrigated with wastewater around the world (FAO, AQUASTAT). Therefore, more robust infrastructure and technology must be developed to reuse this wastewater for irrigation purposes. In the developing countries such as China [4-6], India [7-
10], Pakistan [11,12], South Africa [13,14], Mexico [15], Egypt [16], Iran [17], Qatar [18], Ethiopia [19], Kenya [20], Ghana [21], Peru, Saudi Arabia, Turkey and Lebanon [2] wastewater has been reused for irrigation with or without treatment. In fact, these countries have high population burden that ultimately puts stress on natural water resources for irrigation. Moreover, most of the countries have been facing fresh water shortage and therefore, wastewater irrigation may find a reliable solution to combat such problems. Wastewater irrigation has proven to increase agricultural productivity and allows for multiple cultivation cycles and flexibility of crops planted [22]. Vegetable crop production has been reported to be more pronounced if produced by wastewater [2]. However, environmental and public health risks associated with untreated and partially treated wastewaters have been largely ignored. Developed nations are expanding their use of treated wastewaters for irrigation and have imposed stringent regulations for especially for the production of edible crops to ensure environmental and public 
health safety. While, on the other hand, the developing countries have limited water treatment facilities and have a continuously increasing pressure of population, and hence timely adoption of safe norms for reuse of wastewater becomes more pertinent by deriving experience of the developed nations. Farmers in most of the developing countries who are in need of water for irrigation have generally no other option but to use it without treatment, which can worsen the situation further due to possible presence of pathogens, antibiotics, and other pharmaceutical chemicals.

Wastewater contains different known and unknown contaminants that come in contact with the workers, farmers, agriculture soils and crops during irrigation. Therefore, effective treatment technologies and reuse policies for wastewater irrigation need to be enforced for limiting the negative impact for such practices [23]. Wastewater treatment plants (WWTPs) have been playing an important role in the treatment of wastewater that effectively removes the routine physicochemical and biological contaminations. However, conventional treatment plants are not adequate to limit the microbiological contaminants that resist the disinfection practices and also include antibiotic resistant bacteria [23]. This may pose serious public health problems among exposed population. Moreover, wastewater is known as hot spot of antibiotic resistance in bacteria, which is largely due to selective pressure of antibiotic concentrations and consequently its use for irrigation may further disturb the soil microbial diversity [23]. Therefore, treatment technologies need to focus for an effective removal of pathogens, antibiotic resistant bacteria, and antibiotics from wastewater for safe reuse in irrigation practices. It has been suggested that to achieve the millennium developmental goals (MDGs) both safe water supply and reduction in untreated wastewater reuse are important action to be undertaken [24]. Future prospects of treated wastewater for reuse in irrigation would not involve merely reduction in water scarcity but also the nutrient recovery at a large scale and can help us achieve many of the MDGs including eradication of extreme poverty and providing health and sanitation [24]. This can ultimately add to the economy of the nation as such decentralized systems relieve a lot of stress on fertilizer usage. In this review, the status of wastewater production and treatment is assessed for 15 developing countries on the basis of high population, national water stress ranking (NWSR) and data availability. Data for wastewater irrigation with or without treatment has also been reported on the basis of published reports and peer reviewed papers. Further, the challenges of wastewaters reuse in irrigation such as lack of adequate data; wastewater characterisation; adoption of an appropriate treatment technology, and the perceived policy reforms have been discussed based on a critical examination of the available literature.

Wastewater status in developing countries

Wastewater generation and treatment

Although wastewater generation and treatment data are generally estimated on the basis of urban discharges, it has been reported that $2212 \mathrm{KM}^{3}$ per year are released as wastewater in to the environment, which is more than $50 \%$ of total fresh water withdrawals [25]. Wastewater treatment coverage in high income, upper middle, lower middle and low income countries have been estimated to be approximately $70 \%, 38 \%, 28 \%$ and $8 \%$ respectively [26]. In this study the developing countries, which have been assessed for total wastewater generation and treatment, were selected on the basis of high population, low national water stress rankings (NWSR) and respective data availability (Table 1). Most recent data for total wastewater generation and treatment are reported from India, Mexico and Turkey, while the recent data only for total wastewater treatment are available for Saudi Arabia and Egypt. China and India have reported the maximum wastewater generation primarily due to high population. Egypt was reported to be generating high wastewater than Pakistan and Ethiopia, even with half of the population compared to these countries. India, Iran, Saudi Arabia, Pakistan, Mexico and Lebanon have reportedly been on the top of NWSR. In fact, with high population these countries need an urgent action for wastewater treatment for reducing water footprints.

\section{Wastewater reuse in agriculture irrigation}

Agricultural irrigation accounts for maximum withdrawals of freshwater around the globe. In this study, fresh water withdrawals for irrigation were accounted between 31.96 to 93.95 percent of total freshwater withdrawals from 15 developing countries presented in supplementary table 1 (FAO AQUASTAT). Data show that the highest withdrawals were made by Pakistan and, the lowest by Lebanon. As compared to the previous data of freshwater withdrawals, Lebanon and Qatar were found to have reduced it by more than 40 - 50 percent. This may be due to governmental policies or extreme water scarcity ( 1 and 3 ranks in NWSR). Wastewater reuse in agricultural irrigation has been started in developing countries (27, FAO AQUASTAT) to a good extent. Earlier studies have reported wastewater irrigation data of many countries on the basis of published papers and global database (AQUASTAT FAO), but more recently these data are reported on the basis of total area covered by treated and untreated wastewaters for irrigation [1,26]. In the present study, data for total volume of treated and untreated wastewater for irrigation have been accessed from AQUASTAT FAO for 13 developing countries (data for irrigation was not available for Ghana and Kenya) (Table 2). It shows that data for Iran and Mexico were updated for treated and untreated wastewater volume reuse in irrigation. China, South Africa, Peru, Egypt, Lebanon, and Saudi Arabia reported data only for treated wastewater volume used for irrigation. Pakistan uploaded data only for untreated wastewater reused for irrigation. While no data were updated for India, Turkey and Ethiopia for total treated and untreated wastewater volumes for irrigational purposes. Valipour and Singh (2016) reported the data for total percentage of treated and untreated wastewater used for irrigation. It has been shown that India uses 24 and 74 percent of treated and untreated wastewater for agricultural irrigation respectively [27]. In Ethiopia, 9 million $\mathrm{M}^{3}$ per year of wastewater was used for irrigation [28], however, it was entirely the untreated wastewater [27]. Nas., et al. 2019 reported that Turkey reused 29.6 


\begin{tabular}{|c|c|c|c|c|c|c|c|c|}
\hline $\begin{array}{l}\text { S. } \\
\text { No. }\end{array}$ & Country & $\begin{array}{l}\text { Population } \\
\text { (Millions }\end{array}$ & $\begin{array}{l}\text { National water } \\
\text { stress ranking }\end{array}$ & $\begin{array}{c}\text { Reporting } \\
\text { year }\end{array}$ & $\begin{array}{c}\text { Wastewater gen- } \\
\text { eration }\left(\mathrm{km}^{3} / \text { year }\right)\end{array}$ & $\begin{array}{l}\text { Report- } \\
\text { ing year }\end{array}$ & $\begin{array}{c}\text { Treated waste- } \\
\text { water }\left(\mathbf{k m}^{3} / \text { year }\right)\end{array}$ & References [25] \\
\hline 1 & China & 1386.4 & 56 & 2009 & 58.92 & 2006 & 17.89 & MEPPRC, 2012 \\
\hline 2 & India & 1339.2 & 13 & 2018 & 22.611 & 2018 & 8.2906 & $\begin{array}{l}\text { Gawande and } \\
\text { SSarode, } 2018\end{array}$ \\
\hline 3 & Iran & 81.1628 & 4 & 2010 & 3.548 & 2012 & 0.885 & FAO AQUASTAT \\
\hline 4 & Pakistan & 197.016 & 14 & 2011 & 6.849 & 2011 & 0.548 & Murtaza, 2012 \\
\hline 5 & Mexico & 129.163 & 24 & 2017 & 7.41 & 2017 & 4.28 & FAO AQUASTAT \\
\hline 6 & $\begin{array}{l}\text { South } \\
\text { Africa }\end{array}$ & 56.7172 & 48 & 2009 & 3.542 & 2009 & 1.919 & FAO AQUASTAT \\
\hline 7 & Peru & 32.1655 & 66 & 2011 & 0.995 & 2012 & 0.275 & FAO AQUASTAT \\
\hline 8 & Egypt & 97.5532 & 43 & 2012 & 7.078 & 2017 & 4.282 & FAO AQUASTAT \\
\hline 9 & Lebanon & 6.0824 & 3 & 2011 & 0.31 & 2001 & 0.056 & FAO AQUASTAT \\
\hline 10 & Turkey & 80.745 & 32 & 2016 & 4.499 & 2016 & 3.842 & FAO AQUASTAT \\
\hline 11 & Ethiopia & 104.957 & 96 & 2009 & 0.049 & & NA & $\begin{array}{c}\text { Van Rooijen., et } \\
\text { al. } 2010\end{array}$ \\
\hline 12 & $\begin{array}{l}\text { Saudi } \\
\text { Arabia }\end{array}$ & 32.9382 & 8 & 2010 & 1.546 & 2017 & 1.6 & FAO AQUASTAT \\
\hline 13 & Qatar & 2.6392 & 1 & 2008 & 0.274 & 2017 & 0.2287 & FAO AQUASTAT \\
\hline 14 & Ghana & 28.8336 & 114 & 2006 & 0.28 & 2006 & 0.022 & FAO AQUASTAT \\
\hline 15 & Kenya & 49.6998 & 106 & 2016 & 0.0805 & 2016 & 0.0424 & FAO AQUASTAT \\
\hline
\end{tabular}

Table 1: Country wise population, wastewater generation and treatment status.

Source: Wri.org/aqueduct (https://www.wri.org/blog/2019/08/17-countries-home-one-quarter-worldpopulation-face-extremely-high-water-stress, Last update Jul 6, 2018.

\begin{tabular}{|l|c|c|c|}
\hline $\begin{array}{c}\text { S. } \\
\text { No. }\end{array}$ & Country & Year & $\begin{array}{c}\text { Percent of total water } \\
\text { withdrawal percent }\end{array}$ \\
\hline 1 & China & 2015 & 64.4 \\
\hline 2 & India & 2010 & 90.41 \\
\hline 3 & Iran & 2004 & 92.18 \\
\hline 4 & Pakistan & 2008 & 93.95 \\
\hline 5 & Mexico & 2017 & 76.05 \\
\hline 6 & South Africa & 2017 & 58.77 \\
\hline 7 & Peru & 2016 & 81.37 \\
\hline 8 & Egypt & 2017 & 79.16 \\
\hline 9 & Lebanon & 2015 & 38.04 \\
\hline 10 & Turkey & 2017 & 85.13 \\
\hline 11 & Ethiopia & 2016 & 91.82 \\
\hline 12 & Saudi Arabia & 2017 & 82.23 \\
\hline 13 & Qatar & 2016 & 31.96 \\
\hline 14 & Kenya & 2016 & 80.21 \\
\hline 15 & Ghana & 2000 & 66.4 \\
\hline
\end{tabular}

Supplementary Table 1: Country wise Agricultural Fresh water withdrawals (Source; FAO AQUASTAT [25]).

$\mathrm{m} \mathrm{M}^{3}$ per year treated wastewater [29]. However, no data have been reported for wastewater volume and percent for treated and untreated used for irrigation practices. Data discrepancies for wastewater generation, treatment and reuse for agricultural irrigation have been observed due to partial data availability and in fact not reported for the same duration to facilitate any useful comparison.

Wastewater challenges

Lack of adequate data

Wastewater management demands an updated data set for wastewater generation, treatment and reuse. Recently, global data for wastewater generation, treatment and reuse were reported, which have been collected from 113 countries for wastewater generation, 103 countries for treatment and, 62 countries for wastewater reuse [25]. However, data for wastewater reuse in agricultural irrigation were not reported at global scale. This was justified as underreported data come from the fear some countries have that revealing information may lead to economic sanctions be imposed if low quality water has been used to produce food [30]. There is no global inventory on the extent to which wastewater is used in either treated or untreated form in irrigation. We have compiled data of wastewater irrigation in 13 developing countries from various sources and presented in table 2 . However, only scattered data are available and many times such information is not updated (within 5 years). Developing countries are far lagging behind than developed countries in updating data on wastewater reuse in irrigation. In fact, developing countries have been facing financial crisis, lack of infrastructure development and limited research facility. In some cases, government policies do not provide access to the available information [31]. This makes it difficult for potential researchers and policy makers to understand how to mitigate possible risks and implement preventive measures. 


\begin{tabular}{|c|c|c|c|c|c|c|}
\hline \multirow{3}{*}{$\begin{array}{l}\text { S. } \\
\text { No. }\end{array}$} & \multirow{3}{*}{ Country } & \multicolumn{4}{|c|}{ Wastewater use in irrigation } & \multirow[b]{3}{*}{ References [25 } \\
\hline & & \multicolumn{2}{|r|}{ Treated } & \multicolumn{2}{|c|}{ Not Treated } & \\
\hline & & Reporting year & $\begin{array}{c}\text { Wastewater generation } \\
\left(\mathrm{km}^{3} / \text { year }\right)\end{array}$ & Reporting year & $\begin{array}{c}\text { Treated wastewater } \\
\left(\mathbf{k m}^{3} / \text { year }\right)\end{array}$ & \\
\hline 1 & China & 2012 & 1.26 & & NA & FAO AQUASTAT \\
\hline 2 & India & & & & & \\
\hline 3 & Iran & 2010 & 0.328 & 2005 & 0.244 & FAO AQUASTAT \\
\hline 4 & Pakistan & & & 2006 & 1.022 & FAO AQUASTAT \\
\hline 5 & Mexico & 2010 & 0.401 & 2004 & 4.33 & FAO AQUASTAT \\
\hline 6 & $\begin{array}{l}\text { South } \\
\text { Africa }\end{array}$ & 2009 & 0.006 & & & FAO AQUASTAT \\
\hline 7 & Peru & 2011 & 0.114 & & & FAO AQUASTAT \\
\hline 8 & Egypt & 2011 & 0.29 & & & FAO AQUASTAT \\
\hline 9 & Lebanon & 2011 & 0.004 & & NA & FAO AQUASTAT \\
\hline 10 & Turkey & & & & & \\
\hline 11 & Ethiopia & & & & & \\
\hline 12 & $\begin{array}{l}\text { Saudi } \\
\text { Arabia }\end{array}$ & 2010 & 0.535 & & & FAO AQUASTAT \\
\hline 13 & Qatar & 2016 & 0.0291 & & & FAO AQUASTAT \\
\hline
\end{tabular}

Table 2: Status of treated and untreated Wastewater reuse in irrigation.

Source: FAO AQUASTAT, Obtained on March 31, 2020.

Emerging pollutants in wastewaters

With the beginning of the $21^{\text {st }}$ century, much attention has been paid to occurrence of emerging pollutants such as pathogens [3239], antibiotic resistant bacteria [35,40,45], antibiotics [4-21], pharmaceuticals [15] and micro-plastics in wastewaters, which may impact any reuse policy. In this review, only the presence of antibiotic resistant bacteria, pathogens, and antibiotics in wastewaters has been discussed in the context of developing countries and the role of disinfection has been discussed in mitigating these pollutants in wastewater as a preventive strategy. Following pollutants may pose serious health problems in exposed individuals, farmers and consumers.

\section{Pathogens and antibiotic resistant bacteria (ARB)}

Many recent studies have reported that pathogens and antibiotic resistant bacteria (ARB) are prevalent in wastewaters and its downstream water bodies [32-45]. Wastewaters have been reused in irrigation by direct (WWTPs effluent) or indirect (from WWTPs effluent or untreated in collected downstream) means [46]. Indirect wastewaters reuse has been most commonly practiced in developing countries [46]. In fact, water irrigating users are unaware of wastewater being present (withdrawals from river). These water resources have been contaminated by disposing untreated or partially treated wastewaters from WWTPs, hospitals and industries. Moreover, many countries do not have clear regulatory policies for wastewaters discharge from hospitals [35]. They may discharge potential pathogens and ARB in the receiving water bodies. Recently, In Ethiopia hospital wastewaters that have been discharged in downstream water bodies were evaluated for pathogens and ARB presence. It was reported that pathogens such as Salmonella, Shigella, and S. aureus and potential pathogenic E. coli were detected, some of which were resistant to ceftriaxone, tetracycline, doxycycline and gentamycin [33]. In another study, wastewaters from hospitals and non-hospital environments were collected to evaluate the distribution of multiple drugs resistance (MDR) in bacteria, which found that the overall prevalence of MDR was $69.9 \%$ with the hospital and non hospital wastewaters recording $81.5 \%$ and $54.2 \%$ respectively [34]. Hospitals are hot spots and are playing a major role of disseminating antibiotic resistance in downstream water bodies such as sewer systems, rivers [35]. He reviewed comprehensively on the antibiotic resistance spread from hospitals to municipal WWTPs and its downstream water bodies. Further it has been suggested that antibiotic resistance should be treated as environmental pollution, as large numbers of ARB are released in environment. Therefore, future wastewater treatment methods must be assessed for removal of ARB. However, it is not clear that up to what extent do they contribute to global epidemiology [35]. Global epidemiology of water borne pathogens is high in developing countries and may increase with the reuse of untreated or partially treated wastewaters for irrigational purposes. Recently, microbiological and physicochemical profiles of soil and lettuce were assessed after irrigation with treated wastewaters. Escherichia coli, Arcobacter sp., Aeromonas hydrophila, Bacteroides sp., Bacillus cereus, Legionella sp., and Mycobacterium sp. were present in the irrigation water, as well as in the phyllosphere and rhizosphere of lettuces. However, physicochemical properties of soil and crops have not been altered in short period [36]. A study was conducted at Banaras Hindu University, India, which examined coliforms and viable counts of four potential pathogens Escherichia coli, Salmonella, Clostridium and Vibrio in agricultural irrigated water and vegetables grown in fields in the vicinity of WWTPs during rainy and winter seasons. They found high levels of coliforms count in 
irrigated water in both seasons, with maximum counts observed in spinach and cabbage. Salmonella showed a peak in the dry season [47]. In another study, it was reported that Salmonella was found to contaminate vegetables such as lettuce and parsley, when irrigated with wastewaters. The most frequently observed groups were Salmonella B and C. However, except on lettuce, Salmonella did not persist for more than three days after irrigation [37]. Ibenyassine., et al. (2007) reported that vegetables grown with untreated wastewaters had high level of bacterial contamination. They examined 50 vegetable samples for bacterial contamination after irrigation with wastewaters and found high levels of fecal coliforms, total coliforms and enterococci. Further, biochemical identification of Enterobacteriaceae confirmed the presence of Citrobacter freundii (28\%), Enterobacter cloacae (27\%), Escherichia coli (16\%), Enterobacter sakazakii (12\%), Klebsiella pneumoniae (17\%), Serratia liquefaciens (11\%), and Salmonella arizonae (0.7\%). However, no coagulase-positive Staphylococcus aureus was observed [38]. In another study, presence of helminth eggs screened from wastewaters (treated and untreated) used for irrigated, soil and different grown vegetables was detected. It was observed that untreated wastewater, treated wastewater, soil and vegetable samples were positive for helminth eggs in $83.3 \%, 68.2 \%, 68.6 \%$ and $44.2 \%$ of the cases respectively. These identified eggs were of Ascaris lumbricoides (round worm), Trichuris trichiura (whip worm) and hookworm. The most contaminated vegetable was Pudina and followed by Lettuce, Spinach, Coriander, Celery and Parsley [48]. Similarly, in another study vegetables were found to be contaminated with high concentration of helminth eggs and low concentration of E. coli after irrigation with wastewaters [49]. Emerging water borne pathogens pose serious public health threats in developed and developing nations alike [32]. Earlier, it has been suggested that new infections are likely to increase with re-emerging waterborne pathogens and $\mathrm{ARB}$, with some proofs available in the literature [50]. In developing countries, waterborne diseases such as diarrhea, dysentery, typhoid and cholera are prevalent due to low level of sanitation and hygiene. Further, intrusion of wastewaters in to drinking water resources increases the public health risks [51]. Therefore, waterborne pathogens and ARB must be taken as a challenge, while reuse of wastewaters for irrigation purposes is proposed. New wastewater treatment technologies should focus on the effective removal of potential pathogens and ARB.

\section{Antibiotics in wastewaters}

Despite the presence of different contaminants in wastewaters, antibiotics and ARGs have been recognized as emerging pollutants in environment [26]. Antibiotics have been widely used as medicine to prevent and treat diseases in human as well as in animals [54]. Majority of antibiotics consumed by human and animals, are not metabolized and excreted through faeces and urine in unchanged form [54]. Consequently, this ends up in wastewater treatment plants from where they are released into the water bodies or soils. In a study, many antibiotic (norfloxacin, ofloxacin, ciprofloxacin, enrofloxacin and fleroxacin) concentrations in urban soils were quantified to be in higher concentrations than trigger value (development and selection of resistant bacteria) of $100 \mu \mathrm{g}$ / $\mathrm{kg}$ [52], however, antibiotics concentrations in wastewaters have been reported low in most of the countries [4,14-16]. Moreover, ever increasing use of untreated or partially treated wastewaters for agricultural irrigation may significantly add to unreported exposures to antibiotics adding risks to the human health [6]. The antibiotic concentrations up to many $\mu$ g per kilogram plant tissue were observed in edible crops [27]. In another study, accumulation of antibiotics concentrations in vegetables were ordered as leaves $>$ stem/shoot $>$ root $>$ fruit. However, antibiotics concentration level was lower in vegetable samples than that of soil samples [53]. The potential uptake of antibiotics from soils and wastewaters in irrigated crops is not clearly understood.

Many studies on different antibiotic concentrations in wastewaters (reused for irrigation) have been reported from 11 developing countries (China, India, Pakistan, South Africa, Mexico, Egypt, Iran, Qatar, Ethiopia, Ghana and Kenya), on the basis of availability and presented in table 3. It has also been said that most of the reported studies from developing nations are very recent (within 5 years) and have been indicated to be among the first studies from those locations despite the fact that sewage irrigation was practiced for a long time. In developing countries, China has reported the maximum number of studies on antibiotics concentrations in WWTP effluents and rivers, while the other nations have published very few such studies. These countries have reported studies on different types of antibiotics and differ nation to nation, however, few antibiotics are commonly reported from many countries. Most commonly reported antibiotics are sulfamethoxazole (SMX) and ciprofloxacin (CIP) in more than half of the aforementioned nations, while studies on other antibiotics are sporadic with some of antibiotics being reported in only one country. Therefore, a comparison of any antibiotic concentrations in wastewaters reused for irrigation is not possible, however the data compiled in table 3 indicate relatively high concentration of antibiotics in Ethiopia and Pakistan $[11,12,19]$. On the other hand, antibiotic sulfamethoxazole (SMX) was found to be in high concentration from many countries $[4,5,8,9,13,15,16,20]$ though it was not detected in Ethiopia [19]. Antibiotics Sulfanilamide (SN) and tetracycline (TC) in high concentrations have been reported from Ethiopia [19], while Ghana shows high concentrations of ciprofloxacin (CIP), erythromycin (ERY), sulfamethoxazole (SMX) and trimethoprim (TMP) [21].

In 2015, the WHO launched a global action plan on antimicrobial resistance (AMR) and was endorsed by many developing nations in their national action plans. However, research and surveillance on antibiotics is inadequate till now and the developing nations need to take it up as a big challenge and focus on such studies to combat any serious consequences on human health in future.

\section{Wastewater treatment technologies}

WWTPs are widely used to treat wastewaters received from municipal, industrial and hospital settings [42]. Conventional 


\begin{tabular}{|c|c|c|c|c|c|}
\hline \multicolumn{6}{|c|}{$\begin{array}{l}\text { Antibiotics concentrations in wastewaters used for irrigation (Sources: A-Irrigated waters (ng/L/ B-WWTPs effluents } \\
\text { (ng/L)/ C-river waters (down stream) (ng/L)/ D sediments (ng/kg)) }\end{array}$} \\
\hline Country & Sources & $\mathbf{N}$ & Antibiotics & $\begin{array}{c}\text { Concentrations (with respect to given } \\
\text { antibiotics) }\end{array}$ & References \\
\hline \multirow[t]{3}{*}{ China } & B & & $\begin{array}{l}\text { ARY, CAP, CIP, CLR, ENR, ENX, } \\
\text { LIN, NOR, OFL, OTC, SLCP, } \\
\text { SLD, SLG, SLM, SLP, SMX, TC } \\
\text { and TMP }\end{array}$ & $\begin{array}{c}\text { 1.9-287.5, 10.6, 25.7, } 0.3-115,33.9,148.7 \\
\text { 69.2, 1.6-161.1, 1.2-498.8, 578.7, 15.1 } \\
\text { 150.4, 10.4, 49.7, 50.2, 3.2-780.9, 39.7 } \\
65.3\end{array}$ & 4 \\
\hline & B & & $\begin{array}{l}\text { ARY, CFA, CFM, CLR, CTX, } \\
\text { FLU, NOR, OFL, ROX, SLD, SLP } \\
\text { and SMX }\end{array}$ & $\begin{array}{c}\text { 61.2, 99.3, 61.2, 164, 45.5, 30.4, 1018, } \\
1481,1419,708,127 \text { and } 506\end{array}$ & 5 \\
\hline & $\mathrm{B}$ & & OFL, OTC and SMX & $916.88,337.81$ and 106.6 & 6 \\
\hline \multirow[t]{5}{*}{ India } & $\mathrm{B}$ & & AMX & 62.5 & 7 \\
\hline & $\mathrm{C}$ & & ARY, CLR, SMX and TMP & $\begin{array}{l}990 \pm 558,12 \pm 2-51 \pm 55,11 \pm 1-816 \pm \\
241 \text { and } 24 \pm 6-59 \pm 8\end{array}$ & 8 \\
\hline & $\mathrm{B}$ & & ERY, SMX and TMP & 130,3200 and 1000 & 9 \\
\hline & B & & AMP, CEF, CIP, GAT and SPA & $\begin{array}{l}6300-27100,600,2900-17700,3700 \text { and } \\
500\end{array}$ & 10 \\
\hline & $\mathrm{C}$ & & AMP, CEF, CIP, GAT and SPA & $200-13750,1700,1440,480$ and 2090 & \\
\hline \multirow[t]{2}{*}{ Pakistan } & $\mathrm{B}$ & & CIP, GEM, MEV, OFL and SPA & $18000,200,224000,66000$ and 58000 & 11 \\
\hline & B & & CIP, ENR and LEV & $\begin{array}{l}15800-341000,11000-260000 \text { and } \\
13000-368000\end{array}$ & 12 \\
\hline \multirow[t]{2}{*}{ South Africa } & B & & $\begin{array}{l}\text { ALB, ARY, CIP, CLI, CLR, ERY, } \\
\text { ETI, MEI, NOR, OFL, ROX, } \\
\text { SMX and TMP }\end{array}$ & $\begin{array}{c}0-682.7,0-0.7,61.2-707.6,0.5-8.1,0.2- \\
37.7,0.1-18.2,0.2-9.3,1.2-17.9,0-1.1,9.3- \\
65.6,0,59.3-353.9 \text { and } 9.6-161.8\end{array}$ & 13 \\
\hline & $\mathrm{B}$ & & FLO and SMX & $68 \pm 33-92 \pm 29$ and $76 \pm 23-121 \pm 28$ & 14 \\
\hline Mexico & $\mathrm{B}$ & & CIP, OFL, SMX and TMP & $0,290 \pm 0.23,630 \pm 0.8$ and $550 \pm 0.8$ & 15 \\
\hline Egypt & $\mathrm{B}$ & & ARY, CIP and SMX & 310,250 and 1720 & 16 \\
\hline Iran & B & & AMX, CFI and IMP & $\begin{array}{l}580 \pm 270-890 \pm 420,4100 \pm 1200-4940 \\
\quad \pm 2500 \text { and } 5730 \pm 2600-7800 \pm 2390\end{array}$ & 17 \\
\hline Qatar & B & & $\begin{array}{l}\text { AMX, CIP, CLA, ERY, MET, PEN } \\
\text { and TC }\end{array}$ & $\begin{array}{l}84,238-1723,3359-44783,167,331 \\
419 \text { and } 260\end{array}$ & 18 \\
\hline Ethiopia & $\mathrm{D}$ & & $\begin{array}{c}\text { CIP, CTC, DC, ENR, NOR, OFL, } \\
\text { OTC, SLD, SME, SMX, SN and } \\
\text { TC }\end{array}$ & $\begin{array}{c}\text { ND, } 15400,7380,8750,4580,18350, \\
37300,1090-15810,7980, N D, 25980 \text { and } \\
62390\end{array}$ & 19 \\
\hline \multirow[t]{2}{*}{ Kenya } & $\mathrm{B}$ & & CIP, SMX and TMP & 67,3336 and 66 & \multirow[t]{2}{*}{20} \\
\hline & $\mathrm{C}$ & & CIP, SMX and TMP & 509,13765 and 2650 & \\
\hline \multirow[t]{3}{*}{ Ghana } & A & 18 & $\begin{array}{c}\text { AMX, AMP, CEF, CIP, CTC, DC, } \\
\text { ERY, MET, OTC, SMX, TC and } \\
\text { TMP }\end{array}$ & $\begin{array}{c}1.3,30-74,21-65,47-146,4.3-14,9.4-25 \\
6.7-136,3-33,2.2-9.2,11-56,11-16 \text { and } \\
19-98\end{array}$ & \multirow[t]{3}{*}{21} \\
\hline & B & 9 & $\begin{array}{c}\text { AMX, AMP, CEF, CIP, CTC, DC, } \\
\text { ERY, MET, OTC, SMX, TC and } \\
\text { TMP }\end{array}$ & $\begin{array}{c}1.3,51-97,58-345,27-262,6-19,14-49 \\
47-882,3-19,2.4-24,103-320,11-24 \text { and } \\
31-255\end{array}$ & \\
\hline & $\mathrm{C}$ & 39 & $\begin{array}{c}\text { AMX, AMP, CEF, CIP, CTC, DC, } \\
\text { ERY, MET, OTC, SMX, TC and } \\
\text { TMP }\end{array}$ & $\begin{array}{c}2.7,21-184,32-868,25-1168,5.3-44 \\
8.3-68,7-1149,363,3-26,13-2861,11-30 \\
17-820\end{array}$ & \\
\hline
\end{tabular}

Table 3: Antibiotics concentrations in irrigation water from developing countries.

Abbreviations: AMX: Amoxicillin; AMP: Ampicillin; ARY: Azithromycin; CFI: Cefixime; CFA: Cephazoli; CFM: Cephametazole; CTX: Cefotaxime; CEF: Cefuroxime; CAP: Chloramphenicol; CIP: Ciprofloxacin; CLR: Clarithromycin; CLA: Clavulanic acid; CTC: Cyclotetracycline; DC: Doxycycline; ENR: Enroflaxin; ENX: Enoxacin; ERY: Erythromycin; FLO: Fluoroquinolones; GEM: Gemifloxacin; IMP: Imipenem; LEV: Levofloxacin; LIN: Lincomycin; MET: Metronidazole; MEV: Moxifloxacin; NOR: Norfloxacin; OFL: Ofloxacin; OTC: Oxytetracycline; ROX: Roxithromycin; SPA: Sparfloxacin; SLD: Sulfadiazine; SMX: Sulfamethoxazole; SN: Sulfanilamide; SLP: Sulfapyridine; TC: Tetracyclin; TMP: Trimethoprim; SLG: Sulfaguanidine; SLM: Sulfamethazine; SLCP: Sulfachlorpyradazine; FLM: Flumequine; GAT: Gatifloxacin; ETI: Ethionamide; ALB: Albendazole; CFL: Cephalexin; GEN: Gentamycin; PEN: Penicillin; SME: Sulfameter 
treatments plants have been effectively limit the physicochemical parameters but not effective in the removal of antibiotics, ARBs and potential pathogens from wastewaters $[4,7,16,42,55]$. This is the biggest challenge for currently adopted wastewater treatment technology around the world. However, disinfection methods have been adopted to inactivate the microbiological contaminations. What are the challenges of disinfection methods? There is no single disinfection method found to inactivate all the pathogenic bacteria in treated wastewaters. Chlorination is most practised disinfection method in developing countries because of its economic feasibility and effectiveness against wide range of bacteria and viruses. However, in the chlorination process, high doses of chlorine are required due to certain chlorine resistant species and excess of chlorine consumption further give rise to excessive formation of potentially carcinogenic halogenated compounds such as trihalomethanes (THMs) and haloacetic acids (HAAs), many of which are proven human carcinogens and could contaminate downstream water sources and agricultural fields [56]. Shekhawat., et al. (2020) also observed regrowth potential in bacteria after chlorination. This is why; developed nations have been adopted other disinfection methods such as UV irradiation and ozonation. Ozone has been proven to be one of the most effective disinfectants and is widely used to inactivate pathogens and to remove other organic compounds. It is effective in destroying microorganisms which are resistant to most other disinfectants. There are no harmful residuals and no regrowth of microorganisms reported but it is a complex technology, which is extremely reactive, corrosive and not economical. Ozone gas is extremely irritating and toxic [57]. UV light can be used as an alternative to chlorine, or other chemicals for disinfection. As no chemicals are used, the treated water has no residuals that can have an adverse effect on aquatic organisms that later consume it. The key disadvantages of UV disinfection are the need for frequent lamp maintenance and replacement and the need for a pre-treated effluent to ensure that the target microorganisms are not shielded from the UV radiation [58]. Therefore, from the previous studies, it was perceived that each disinfectant had some shortcomings and it could be overcome by the hybrid approach [59].

Many studies have been suggested for the investigation and optimization of hybrid disinfection (Chlorine + UV/ UV+ Chlorine) methods for the control of pathogens, antibiotic resistant bacteria and disinfection byproducts [55,59]. Hybrid disinfection strategies are aimed to avoid high doses of chlorine by adopting a serial step of another disinfectant that has the potential to remove chlorine resistant species and optimize the overall disinfection process. Such hybrid strategies also modify the DBP formation apart from comparably reducing the overall cost of the process. A comparative study was conducted for the removal of ARB from treated wastewater effluent using chlorination, UV irradiation and ozonation, which concluded that UV irradiation was the most efficient for the removal of ARB, while ozonation was the least effective [60]. However, conventional disinfection (chlorination and UV irradiation) is not effective in the removal of ARBs from wastewaters [61].
On the other hand, antibiotics residual in wastewaters may pose a serious public health problem as discussed previously. Chlorination has been performed for antibiotic residual removal but no significant removal was observed. Antibiotic residual rate was greatly varied due to suspended solids, ammonia and $\mathrm{pH}$ [62]. However, a $100 \mathrm{mg} / \mathrm{L}$ chlorine dose effectively removes antibiotics from wastewater [63]. In case of UV irradiation, antibiotic photoproducts have been found to preserve parent compound and have observed with increased toxicity [64]. However, toxicity was reduced, while using combined oxidation of $\mathrm{UV} / \mathrm{H}_{2} \mathrm{O}_{2}$. Therefore, it is a big challenge to find an efficient and suitable method for the removal of such pollutants. Advanced oxidation can converts complex antibiotic molecule in to simpler form but high cost input makes it unsuitable for the developing nations [65]. There are physicochemical processes have been employed for the removal of antibiotics from wastewaters. Adsorption process is simple and efficient for the removal of antibiotics. It has been reported that it can be remove antibiotics in $\mathrm{mg} / \mathrm{L}$ concentration. This is high enough to remove antibiotic concentrations (ng/L - $\mu \mathrm{g} / \mathrm{L}$ ) in wastewaters (Table 3). There are various adsorbents such as activated carbon, carbon nanotubes, biochar, bentonite and ion exchange resins have been used for removal of antibiotic residuals. However, effective adsorbents such as activated carbon and carbon nanotubes are expensive due to high material and regeneration cost. Future research challenge is to investigate, modify and produce low cost adsorbents for the removal of antibiotics from wastewaters.

\section{Policies for wastewater reuse in irrigation}

Wastewater reuse is becoming a global need to sustain the future life around the world. However, it is essential to reuse it safely. Therefore, it is mandatory to promulgate certain policies and must be updated regularly through new guidelines, on the basis of the conclusions of ongoing research studies. These guidelines may differ for different geographical locations due to vast differences in reported pollutants in their wastewaters as well as those of the receiving water bodies or soil. Current guidelines suggested by the World Health Organization (WHO) and environmental protection act (EPA) are primarily based on inadequate epidemiological data, rather than a long term risk assessment. For example, WHO identified that the presence of helminths connotes a real danger because of their resistance and survival in the environment. However, in developing nations, norms do not usually relate helminths and protozoa. In fact, in these nations intestinal worm diseases are low among population [1]. On the other hand, in the developing countries microbiological contamination in wastewater can be up to 1000 times higher than that found in the developed nations. Moreover, high concentrations of antibiotics in wastewaters have been reported from developing countries as discussed previously. This is consequently increasing the antibiotic resistance in bacterial population surviving in wastewaters [13]. Therefore, it is suggested to propose limits for antibiotics concentrations and ARBs counts in future guidelines of wastewater reuse in agriculture irrigation. However, comprehensive studies on risk assessments of such pollutants need to be conducted and validated. 


\section{Future Prospects}

In developing countries, the reuse of large volumes of wastewater generated can play a major role in reducing water foot prints and act as an economy booster. However, an integrated approach of wastewater treatment processes needs to be developed for safe reuse in agricultural irrigation, which has a high demand of water to produce foods. Wastewater has now come up as a new water resource to fulfil the demands of future generation. Innovations in the field of wastewater treatment can not only improve sanitation and hygiene conditions and minimize the pressure of water borne diseases, but also improve the long term economic sustainability. In fact, wastewater management cannot be efficient without involving integrative strategies in regulatory policies, institutional dialogues and financial mechanisms [43]. Such strategies warrant safety of water reuse, therefore should be based on adequately developed water quality standards appropriate to agricultural irrigation for a sustainable and enhanced food productivity.

\section{Bibliography}

1. Jaramillo MF and Restrepo I. "Wastewater reuse in agriculture: A review about its limitations and benefits". Sustainability 9.10 (2017):1734.

2. Keraita B., et al. "Extent and implications of agricultural reuse of untreated, partly treated and diluted wastewater in developing countries". CAB reviews: Perspectives in agriculture, Veterinary Science, Nutrition and Natural Resources 3.58 (2008): 1-15.

3. Pearce G. "UF/MF pre-treatment to RO in seawater and wastewater reuse applications: a comparison of energy costs". Desalination 222 (2008): 66-73.

4. Zhang X., et al. "Occurrence, removal, and risk assessment of antibiotics in 12 wastewater treatment plants from Dalian, China". Environmental Science and Pollution Research 24.19 (2017): 16478-16487.

5. Wang W., et al. "Occurrence and fate of typical antibiotics in wastewater treatment plants in Harbin, North-east China". Frontiers of Environmental Science and Engineering 13.3 (2019): 34.

6. Wu M., et al. "Distribution, fate, and risk assessment of antibiotics in five wastewater treatment plants in Shanghai, China". Environmental Science and Pollution Research 23.18 (2016): 18055-18063.

7. Mutiyar PK and Mittal AK. "Occurrences and fate of selected human antibiotics in influents and effluents of sewage treatment plant and effluent-receiving river Yamuna in Delhi (India)". Environmental Monitoring and Assessment 186.1 (2014): 541-557.

8. Prabhasankar VP., et al. "Removal rates of antibiotics in four sewage treatment plants in South India". Environmental Science and Pollution Research 23.9 (2016): 8679-8685.
9. Williams M., et al. "Emerging contaminants in a river receiving untreated wastewater from an Indian urban centre". Science of the Total Environment 647 (2019): 1256-1265.

10. Mutiyar PK and Mittal AK. "Occurrences and fate of an antibiotic amoxicillin in extended aeration-based sewage treatment plant in Delhi, India: a case study of emerging pollutant". Desalination and Water Treatment 51.31-33 (2013): 6158-6164.

11. Riaz L., et al. "Industrial release of fluoroquinolones (FQs) in the waste water bodies with their associated ecological risk in Pakistan". Environmental Toxicology and Pharmacology 52 (2017): 14-20.

12. Ashfaq M., et al. "Occurrence and ecological risk assessment of fluoroquinolone antibiotics in hospital waste of Lahore, Pakistan". Environmental Toxicology and Pharmacology 42 (2016): 16-22.

13. Faleye AC., et al. "Concentration and reduction of antibiotic residues in selected wastewater treatment plants and receiving waterbodies in Durban, South Africa". Science of The Total Environment 678 (2019): 10-20.

14. Hendricks R and Pool EJ. "The effectiveness of sewage treatment processes to remove faecal pathogens and antibiotic residues". Journal of Environmental Science and Health, Part A 47.2 (2012): 289-297.

15. Calderón A., et al. "Pharmaceuticals present in urban and hospital wastewaters in Mexico City". Journal of Water Chemistry and Technology 41.2 (2019): 105-112.

16. Younes HA., et al. "Seasonal occurrence, removal efficiency and associated ecological risk assessment of three antibiotics in a municipal wastewater treatment plant in Egypt". Environmental Nanotechnology, Monitoring and Management 12 (2019): 100239.

17. Shokoohi R., et al. "Evaluation of the Efficiency of Wastewater Treatment Plants in the Removal of Common Antibiotics from Municipal Wastewater in Hamadan, Iran". Avicenna Journal of Environmental Health Engineering 4.1 (2017): e10921.

18. Al-Maadheed S., et al. "Antibiotics in hospital effluent and domestic wastewater treatment plants in Doha, Qatar". Journal of Water Process Engineering 28 (2019): 60-68.

19. Ergie AA., et al. "Antibiotics and Resistance Genes in Awash River Basin, Ethiopia”. Eco Health 16.3 (2019): 441-453.

20. Ngumba E., et al. "Occurrence of selected antibiotics and antiretroviral drugs in Nairobi River Basin, Kenya". Science of the Total Environment 539 (2016): 206-213.

21. Azanu D., et al. "Occurrence and risk assessment of antibiotics in water and lettuce in Ghana". Science of the Total Environment 622 (2018): 293-305. 
22. Raschid-Sally L., et al. "Managing wastewater agriculture to improve livelihoods and environmental quality in poor countries". Irrigation and Drainage 54.1 (2005): 11-22.

23. Rizzo L., et al. “Urban wastewater treatment plants as hotspots for antibiotic resistant bacteria and genes spread into the environment: a review". Science of the Total Environment 447 (2013): 345-360.

24. Lawanson TO. "Challenges of sustainability and urban development in Nigeria: reviewing the Millennium Development Goals". Globalization, Culture and the Nigerian Built Environment 2 (2005): 366-372.

25. AQUASTAT. "Area Equipped for Irrigation". Infographic. Rome, Food and Agricultural Organization of the United Nations (FAO) (2014).

26. Sato T., et al. "Global, regional, and country level need for data on wastewater generation, treatment, and use". Agricultural Water Management 130 (2013): 1-13.

27. Valipour M and Singh VP. “Global experiences on wastewater irrigation: challenges and prospects". In Balanced urban development: options and strategies for Liveable Cities (2016): 289327.

28. Van Rooijen DJ., et al. "Urban growth, wastewater production and use in irrigated agriculture: a comparative study of Accra, Addis Ababa and Hyderabad". Irrigation and Drainage Systems 24.1-2 (2010): 53-64.

29. Nas B., et al. "Wastewater reuse in Turkey: from present status to future potential". Water 20.1 (2020): 73-82.

30. Mc Cornick PG., et al. "From wastewater reuse to water reclamation: progression of water reuse standards in Jordan". Wastewater use in Irrigated Agriculture: Confronting the Livelihood and Environmental Realities (2004): 153-162.

31. Qadir M., et al. "The challenges of wastewater irrigation in developing countries". Agricultural Water Management 97.4 (2010): 561-568.

32. Sharma S., et al. "Emerging water-borne pathogens". Applied Microbiology and Biotechnology 61.5-6 (2003): 424-428.

33. Fekadu S., et al. "Assessment of antibiotic-and disinfectantresistant bacteria in hospital wastewater, south Ethiopia: a cross-sectional study". The Journal of Infection in Developing Countries 9.02 (2015): 149-156.

34. Moges F., et al. "Isolation and characterization of multiple drug resistance bacterial pathogens from waste water in hospital and non-hospital environments, Northwest Ethiopia". BMC Research Notes 7.1 (2014): 215.

35. Hocquet D., et al. "What happens in hospitals does not stay in hospitals: antibiotic-resistant bacteria in hospital wastewater systems". Journal of Hospital Infection 93.4 (2016): 395-402.
36. Cui B and Liang S. "Monitoring Opportunistic Pathogens in Domestic Wastewater from a Pilot-Scale Anaerobic Biofilm Reactor to Reuse in Agricultural Irrigation". Water 11.6 (2019): 1283.

37. Melloul AA., et al. "Salmonella contamination of vegetables irrigated with untreated wastewater". World Journal of Microbiology and Biotechnology 17.2 (2001): 207-209.

38. Ibenyassine K., et al. "Bacterial pathogens recovered from vegetables irrigated by wastewater in Morocco". Journal of Environmental Health 69.10 (2007): 47-51.

39. Rai PK and Tripathi BD. "Microbial contamination in vegetables due to irrigation with partially treated municipal wastewater in a tropical city". International Journal of Environmental Health Research 17.5 (2007): 389-395.

40. Al-Jassim N., et al. "Removal of bacterial contaminants and antibiotic resistance genes by conventional wastewater treatment processes in Saudi Arabia: is the treated wastewater safe to reuse for agricultural irrigation?" Water Research 73 (2015): 277-290.

41. Pan M and Chu LM. "Occurrence of antibiotics and antibiotic resistance genes in soils from wastewater irrigation areas in the Pearl River Delta region, southern China". Science of the total Environment 624 (2018): 145-152.

42. Al-Gheethi AA., et al. "Removal of pathogenic bacteria from sewage-treated effluent and biosolids for agricultural purposes". Applied Water Science 8.2 (2018): 74.

43. Shekhawat SS., et al. "Investigation of chlorine tolerance profile of dominant gram negative bacteria recovered from secondary treated wastewater in Jaipur, India". Journal of Environmental Management 255 (2020): 109827.

44. Huang C., et al. "Environmental transport of emerging humanpathogenic Cryptosporidium species and subtypes through combined sewer overflow and wastewater". Applied and Environmental Microbiology 83.16 (2017): e00682-e00617.

45. Piña B., et al. "On the contribution of reclaimed wastewater irrigation to the potential exposure of humans to antibiotics, antibiotic resistant bacteria and antibiotic resistance genesNEREUS COST Action ES1403 position paper". Journal of Environmental Chemical Engineering (2018): 102131.

46. Jeong H., et al. "Irrigation water quality standards for indirect wastewater reuse in agriculture: a contribution toward sustainable wastewater reuse in South Korea". Water 8.4 (2016):169.

47. Rai PK and Tripathi BD. "Microbial contamination in vegetables due to irrigation with partially treated municipal wastewater in a tropical city". International Journal of Environmental Health Research 17.5 (2007): 389-395. 
48. Gupta N., et al. "Prevalence of intestinal helminth eggs on vegetables grown in wastewater-irrigated areas of Titagarh, West Bengal, India". Food Control 20.10 (2009): 942-945.

49. Ensink JH., et al. "Wastewater-irrigated vegetables: market handling versus irrigation water quality". Tropical Medicine and International Health 12 (2007): 2-7.

50. Lederberg J., et al. "Emerging infections. Microbial threats to health in the United States". National Academy Press, Washington, D.C (1992).

51. Pirsaheb M., et al. "Prevalence of the waterborne diseases (diarrhea, dysentery, typhoid, and hepatitis A) in West of Iran during 5 years (2006-2010)". Annals of Tropical Medicine and Public Health 10.6 (2017): 1524.

52. Gao L., et al. "Occurrence and distribution of antibiotics in urban soil in Beijing and Shanghai, China". Environmental Science and Pollution Research 22.15 (2015): 11360-11371.

53. Hussain S., et al. "Accumulation of residual antibiotics in the vegetables irrigated by pharmaceutical wastewater". Exposure and Health 8.1 (2016): 107-115.

54. McArdell CS., et al. "Occurrence and fate of macrolide antibiotics in wastewater treatment plants and in the Glatt Valley Watershed, Switzerland". Environmental Science and Technology 37.24 (2003): 5479-5486.

55. Ben W., et al. "Distribution of antibiotic resistance in the effluents of ten municipal wastewater treatment plants in China and the effect of treatment processes". Chemosphere 172 (2017): 392-398.

56. Verma K., et al. "A review on sewage disinfection and need of improvement". Desalin Water Treat 56.11 (2014): 2867-2871.

57. USEPA. "Wastewater technology fact sheet: ozone disinfection." Washington, DC, EPA (1999).

58. TK Das. "Ultraviolet disinfection application to a wastewater treatment plant". Clean Products and Processes 3.2 (2001): 6980.

59. Verma K., et al. "Optimization of chlorination process and analysis of THMs to mitigate ill effects of sewage irrigation". Journal of Environmental Chemical Engineering 5.4 (2017): 3540-3549.

60. Liu YL., et al. "Enhanced Antibiotic Resistant Bacteria Removal from Wastewater Treatment Plant by Different Disinfection Technologies". Huan jing ke xue= Huanjing kexue 38.10 (2017): 4286-4292.

61. Rizzo L., et al. "Advanced treatment of urban wastewater by UV radiation: effect on antibiotics and antibiotic-resistant E. coli strains". Chemosphere 92.2 (2013): 171-176.
62. Li B and Zhang T. "Different removal behaviours of multiple trace antibiotics in municipal wastewater chlorination". Water Research 47.9 (2013): 2970-2982.

63. Qiang Z., et al. "Treatment of antibiotics and antibiotic resistant bacteria in swine wastewater with free chlorine". Journal of Agricultural and Food Chemistry 54.21 (2006): 8144-8154.

64. Yuan F., et al. "Photodegradation and toxicity changes of antibiotics in UV and UV/H2O2 process". Journal of Hazardous Materials 185.2-3 (2011): 1256-1263.

65. Mehrjouei M., et al. "Energy consumption of three different advanced oxidation methods for water treatment: a cost-effectiveness study". Journal of Cleaner Production 65 (2014): 178-183.

\section{Assets from publication with us}

- Prompt Acknowledgement after receiving the article

- Thorough Double blinded peer review

- Rapid Publication

- Issue of Publication Certificate

- High visibility of your Published work

Website: www.actascientific.com/

Submit Article: www.actascientific.com/submission.php

Email us: editor@actascientific.com

Contact us: +919182824667 